\title{
UM JANTAR ACACIANO: NA MEDIDA PARA A CRÍTICA GASTRONÔMICA DA BURGUESIA LISBOETA ${ }^{1}$
}

\author{
José Roberto de Andrade \\ (Universidade Federal da Bahia/ \\ Instituto Federal da Bahia)
}

\section{RESUMO}

Eça de Queirós (1845-1900) não se destacou como grande cozinheiro, mas sua literatura deixou marcas na cozinha portuguesa. A culinária é tão importante em sua obra que inspirou livro de receitas e chamou a atenção de leitores ilustres. Este trabalho procura enfatizar a importância da gastronomia na estruturação d'O Primo Basílio. Compondo gastronomicamente seus personagens, Eça exercita a crítica e destaca as singulares condições, perspectivas e limitações da sociedade portuguesa do século XIX. As refeições do romance concretizam o descompasso entre o ideal de grandeza e a pequenez cotidiana, a estereotipia do olhar destinado ao outro e a reificação das relações humanas.

PALAVRAS-CHAVE: Literatura Portuguesa, gastronomia, O Primo Basílio.

\section{ABSTRACT}

Although Eça de Queirós (1845-1900) has not stood out as a great cook, his literature has left traces in Portuguese cuisine. In fact, culinary is such a relevant element in his books that his work has inspired a recipe book and called attention of illustrious readers. This paper highlights the relevance of gastronomy in the structuring of O Primo Basílio. By gastronomically portraying his characters, Eça exercises his criticism and stresses the singular conditions, perspectives and limitations of nineteen-century Portuguese society. The meals portrayed in the aforementioned novel provides concrete expression to the imbalance between the ideal of grandeur and the pettiness of everyday life, the stereotyping look towards the other(s) and the reification of human relations.

KEYWORDS: Portuguese Literature, gastronomy, O Primo Basílio. 
Eça de Queirós (1845-1900) não se destacou como grande cozinheiro, mas sua literatura deixou marcas na cozinha portuguesa. Talvez seja possível ler sua obra numa perspectiva gastronômica e perceber uma elaboração de "receitas" e experimentação de "ingredientes". O escritor português teria, por exemplo, "cozinhado" e "servido" padres e carolas, n'O crime do padre Amaro, a família burguesa, n'O primo Basílio, bacharéis, n’A Relíquia e n'O Mandarim, e a burguesia e nobreza decadentes, n'Os Maias, n'A Ilustre Casa de Ramires e n'As cidades e as serras. O leitor de Eça é constantemente convidado a saborear uma infinidade de entradas, pratos, sobremesas e uma variedade bastante significativa de bebidas: vinhos, licores, águas, champanhe... A comida e o comer podem ser encontrados na quase totalidade da sua obra literária.

E a culinária foi tema de vários textos críticos e jornalísticos. Em artigo publicado na Gazeta de Portugal, em 1867, Eça compara Lisboa a outras cidades históricas. Em tudo encontra semelhanças: Lisboa tem as mesmas sete colinas de Roma; o céu de Lisboa é tão transparente quanto o de Atenas; e tal qual Jerusalém, Lisboa sacrifica os que querem lhe dar alma. Diferentemente de outras cidades, no entanto, "Lisboa o que faz? Come!”. E só se pode ver seu brilho e sua beleza, à noite, depois que a cidade comeu. (III, p. 79) ${ }^{2}$

Lisboa se caracteriza pelo que come, mas os santos devem jejuar: em artigo intitulado "Encíclica Poética", publicado na Revista Moderna em 1897, com fina ironia, Eça de Queirós ataca as orientações do papa Leão XIII sobre a alimentação cristã, afirmando que, se seguissem as orientações do sumo pontífice, os cristãos, além de engordar, nunca seriam santos.

O que entra pela boca das cidades e dos cristãos não foi a única preocupação de Eça. O texto mais exemplar e programático sobre o tema talvez seja o artigo conhecido como "Cozinha Arqueológica”, publicado em 1893, na Gazeta de Notícias. Nele, Eça afirmou: “a mesa constituiu sempre um dos fortes, se não o mais forte alicerce das sociedades humanas" e "O caráter de uma raça pode ser deduzido simplesmente de seu método de assar a carne” (III, p. 1226). As declarações ressaltam a intrínseca relação entre comida e sociedade, que Eça reforça, ao adicionar: "a cozinha e adega exercem uma tão larga e direta influência sobre o homem e a sociedade", por isso "dize-me o que comes, dir-te-ei o que és" (III, p. 1226). Penso que o escritor d'A Relíquia não se incomodaria se acrescentasse "com quem" e "como", a este último período: "diga-me o que comes [como comes e com quem comes] e dir-te-ei quem és”. O acréscimo é apropriado, pois Eça destaca a necessidade de se fazer a "arqueologia" - daí o título do artigo - do sistema culinário greco-romano, ou seja, dizer o que, com quem e como a sociedade comia para entender as relações entre cozinha, processos de cozimento e relações sócio-políticas.

As afirmações de Eça ecoam tratados gastronômicos de época, como Fisiologia do Gosto, publicado em 1825, pelo francês Brillart Savarin, e antecipam afirmações de historiadores como Massimo Montanari (2004), 
para quem os valores do sistema alimentar são resultado da representação dos processos culturais, e a relação humana com os alimentos se estabelece segundo critérios econômicos, nutricionais e simbólicos. Por isso, a comida "se configura como um elemento decisivo da identidade humana e como um dos instrumentos mais eficazes para comunicá-la” (MONTANARI, 2004, p.10). E, na perspectiva da proposta de representação realista da sociedade portuguesa, as proposições de Eça significam, em alguma medida, considerar a cozinha e a comida como forma de caracterizar personagens e sociedade. Comida seria também matéria a ser moldada nas narrativas. Essa interpretação torna-se mais consistente à medida que se lê a obra. $\mathrm{O}$ escritor português não só caracterizou cidade e santos pelo que comem e propôs a observação da cozinha nas sociedades clássicas; ele considerou, em certa medida, a gastronomia como arqué - elemento básico - das representações da sociedade portuguesa. Arqué que foi notada por vários de seus leitores e críticos.

Já em 1878, Machado de Assis, ao ler O Primo Basílio, teve sua atenção despertada pela comida. Na conhecida crítica sobre o romance, Assis arrolou "a pilha de doces", da confeitaria em que se encontram casualmente Sebastião e Juliana, e "o longo jantar do Conselheiro Acácio” entre os itens que configurariam a exagerada preocupação de Eça pelo acessório. A excessiva ênfase nos itens secundários seria decorrente das preocupações com os princípios da escola realista: "O sr. Eça de Queirós não quer ser um realista mitigado, mas intenso e completo" (ASSIS, 1997, p. 908). Naquele momento, sem a visão do todo, Assis não conseguiu intuir que, para ser zeloso com os princípios da escola, Eça poderia ter esquecido a cozinha e dado atenção somente ao guarda-roupa ou à biblioteca. Mas foi zeloso com a comida, também. Machado de Assis viu aí fartura desnecessária. Ao argumento do excesso, pode-se contrapor o da coerência gastronômica que se constitui ao longo da obra. A comida seria um excesso de escola, se Eça não tivesse continuado a ser zeloso com o tema. O cuidado com a comida só fez aumentar de quantidade e qualidade nas obras e versões posteriores, reforçando a hipótese de que o autor de Os Maias pode ter escolhido a cozinha como elemento fundamental de seu projeto de representação de Portugal.

Mais recentemente, a importância da comida nesse projeto de representação foi percebida por vários estudiosos da sua obra. José Werneck (1946), Dario Moreira de Castro Alves (1992), José Quitério (1997), Isabel Pires de Lima (1997), Beatriz Berrini (1995 e 1997), Maria José de Queirós (2004), Alfredo de Campos Matos (1988 e 2012) e Ana Luísa Vilela (1997 e 2012) notaram que o tratamento zeloso da comida não foi, como imaginou Machado de Assis, um exagero de escola. Nas narrativas ecianas, as cenas gastronômicas estruturam o ambiente moral e material, servem à caracterização das personagens, ao desenvolvimento do enredo e ao exercício da crítica e da sátira. Assim, a cozinha ordena o universo narrativo de Eça e revela uma importante possibilidade de interpretação de seu projeto de representação da sociedade portuguesa. 
Em artigos anteriores (ANDRADE, 2012 e 2013) procurei destacar como esse projeto se materializa em $O$ Crime do Padre Amaro, Os Maias, A Relíquia e O Mandarim. Aqui, analisarei o longo jantar - como Machado de Assis o qualificou - oferecido por Conselheiro Acácio, para comemorar sua nomeação "ao Grau de Cavaleiro da Ordem de São Tiago, atendendo aos seus grandes merecimentos literários, às obras publicadas de reconhecida utilidade, e mais partes..." (I, p. 678). A análise procurará exemplificar como Eça de Queirós elabora e "tempera”, com esmero e cuidado, personagens e enredo.

Como sugeri no parágrafo inicial, o ingrediente principal d'O Primo Basílio, publicado em 1880, é a família da burguesia média de Lisboa. O romance inicia-se com Jorge e Luísa vivendo o idílio, a placidez e a estabilidade de um casamento burguês. As exigências do trabalho de Jorge, um engenheiro de minas, levam-no a viajar pelo Alentejo e deixar Luísa, solitária e entediada, em Lisboa. Nesse momento, volta do Brasil o primo Basílio de Brito, com quem Luísa conviveu e namorou na adolescência. Ele se reaproxima da prima, inicia um jogo de sedução e é correspondido. E “o adultério de Luísa é a causa de sua destruição” (REIS, 2000, p. 50). A criada, Juliana, apodera-se de uma carta de amor dirigida a Basílio e chantageia a patroa. Com a ajuda de Sebastião, amigo fiel do casal, a carta é recuperada e Juliana morre, mas Jorge descobre a traição e o final é trágico também para Luísa. No capítulo XI, em que o jantar acontece, Jorge já voltou do Alentejo, mas ainda não suspeita da traição da esposa.

Alfredo de Campos Matos caracterizou Acácio como "símbolo da gravidade balofa e da respeitabilidade burguesa convencional" (MATOS, 2009 , p. 447). A personagem cultiva essas características mantendo relações amistosas com figuras da burguesia lisboeta, entre elas Jorge e Luísa, fazendo declarações laudatórias aos poderes estabelecidos e produzindo "obras patrióticas", que vão lhe render, também, sua nomeação ao Grau de Cavaleiro da Ordem de São Tiago.

Vimos anteriormente que a "arqueologia" gastronômica deve considerar três aspectos: a comida (o que comes), a companhia (com quem comes) e o comportamento à mesa (como comes). Por uma questão de lógica argumentativa, começarei pelo segundo item; passarei ao terceiro e, por fim, voltarei ao primeiro.

\section{COM QUEM COMES}

Acácio convida os amigos "para um [...] modesto jantar de rapazes, no seu humilde tugúrio” (I, p. 678). Além do anfitrião, serão cinco os convidados. Três já conhecidos do leitor, nos primeiros capítulos do romance: i) Jorge, engenheiro de minas, funcionário do Ministério das Obras Públicas, marido de Luísa; ii) Sebastião, proprietário de terras e de "inscrições", de "vida saudável e hábitos castos", bom pianista, e amigo fiel e íntimo de Jorge; e iii) Julião, cirurgião, irônico, materialista, inconformado 
com sua situação de pobreza, sem clientes, enquanto outros, menos inteligentes e capazes, sobem na vida. Na casa do Conselheiro, eles vão partilhar a mesa com mais dois convivas:

O Sr. Alves Coutinho

era picado das bexigas, tinha a cabeça muito enterrada nos ombros; quando o seu olhar parvo se fixava nas pessoas, com pasmo, o seu bigode pelado arreganhava-se logo por hábito, num sorriso alvar que mostrava uma boca medonha cheia de dentes podres; falava pouco, esfregava sempre as mãos, concordava em tudo; havia nele o ar de um deboche banal e de um embrutecimento antigo. Era um empregado do ministério do Reino, ilustre pela sua boa letra. (I, p. 679)

E o conhecido Saavedra,

redator do Século. A sua face branca parecia mais balofa; o bigode muito preto reluzia de brilhantina; as lunetas de ouro acentuavam o seu tom oficial; trazia ainda no queixo o pó-de-arroz, que lhe pusera momentos antes o barbeiro; e a mão, que escrevia tanta banalidade e tanta mentira, vinha aperreada numa luva nova, cor de gema de ovo. (I, p. 679)

Anfitrião e convidados compõem uma boa e diversificada representação da burguesia média masculina da Lisboa do XIX: Jorge, Julião e Sebastião, já apresentados, mais um funcionário do reino, dono de boa letra, ar debochado, dentes podres e sorriso tolo; e um mentiroso redator do Século. Essa diversidade também vai garantir uma conversação animada: o inconformado Julião e o mentiroso Saavedra vão apimentar a conversa com provocações dirigidas os pacatos Jorge, Sebastião e, principalmente, Acácio, que também terá o papel de mediador dos debates. Alves Coutinho vai concordar e se satisfazer com o que for conveniente.

\section{COMO COMES}

O comportamento à mesa deve ser entendido num sentido bastante amplo. Ele abrange desde mastigação e manejo de talheres até a conversação. Aqui, tratarei da relação de anfitrião e convidados com talheres, bebidas e comida e da conversação.

As atitudes de anfitrião e convidados só seriam modelos para um Cavalheiro da Ordem de São Tiago, se considerássemos a conhecida ironia de Eça de Queiros, que vai pinçar e qualificar os gestos, trejeitos e hábitos das personagens, para confirmar e reforçar a descrição que se fez deles. Dos seis, só Jorge e Sebastião são poupados da crítica mais direta. Os outros serão tratados com acrimônia.

A severidade dedicada a Julião e Acácio é menor. Enquanto Filomena, uma das criadas, serve vitela assada, o primeiro pousa "os cotovelos sobre a mesa" e escabicha "os dentes com a unha" (I, p. 683). E o segundo é flagrado usando o garfo como extensão do dedo: "Não dê ouvidos a estas 
doutrinas! - Com o garfo mostrava a figura biliosa de Julião. — Mantenha a sua alma pura" (I, p. 683).

A Alves Coutinho e Saavedra, Eça dispensa um tratamento mais áspero. Saavedra, num dos momentos do jantar, "esvaziou o copo e limpou os beiços", para, em seguida, meter "as mãos nos bolsos, firmando-se nas costas da cadeira" (I, p. 683). Ele também conversa e pede "mais arroz. Devorava" (I, p. 682). Nos momentos em que o diálogo é tenso ou que não é conveniente se posicionar, ele enche "a boca de vitela" (I, p. 684) ou "calava-se, ocupado com o alimento". E para arrematar: desabotoa "a fivela do colete"; "espalhava-se-lhe no rosto gordo uma cor de enfartação, e sorria vagamente, inchado" (I, p. 685). Alves Coutinho é pintado de "olho afogado" pelo "cozidinho" (I, p. 681), que prefere ao peixe e ao assado. Também usa uma estratégia típica dos glutões para demonstrar prudência no falar sobre assuntos espinhosos: "calava-se, [...] engolindo buchas de pão" (I, p. 684). Nas pilherias e provocações de Saavedra, Coutinho demonstra prazer, e sua boca "dilatava-lhe numa admiração sensual" (I, p. 682). Dessa personagem, Eça também destaca a paixão incontida pelos "belos doces". No momento da sobremesa, ele se extasia com "a abundância das travessas de doce" e chega a esquecer

as mulheres, e, voltado para Sebastião, discutia gulodices. Indicava as especialidades: para os folhados, o Cocó! Para as natas, o Baltreschi! Para as gelatinas, o Largo de S. Domingos! Dava receitas; contava proezas de lambarice, revirando os olhos (I, p. 687)

Alves parece preferir doces a mulheres, mas não deixa de procurá-las: "todo o tempo que não dedicava ao serviço do Estado, dividia-o, com solicitude, entre as confeitarias e os lupanares" (I, p. 687). A gula do empregado do Ministério do Reino por doces e a preferência pelos amores de serralho justificam, em certa medida, sua boca cheia de dentes estragados e suas atitudes pouco polidas à mesa. ${ }^{3}$

A relativa falta de polidez à mesa ou, se quisermos adiantar as conclusões, a polidez de ocasião e de aparência vai ser reforçada na conversação, que também caracteriza as personagens. Depois de alguns copos de vinho e champanhe, todos revelam algum detalhe torpe e/ou secreto.

No jantar do Conselheiro, a conversa inicia na constituição italiana, passa pelo casamento, tematiza as mulheres e a política e finda com um brinde à família real. $\mathrm{Na}$ dinâmica da conversação, Acácio é provocado por Julião e Saavedra, mas revela-se hábil para conduzir o diálogo e manter a "respeitabilidade do lar burguês". Como a cena é extensa, procurarei sumarizar algumas passagens e dar destaque a dois ou três momentos, começando pela intenção do Anfitrião: "Conselheiro que julgava do seu dever dar à conversação nobreza e interesse, disse, limpando devagar o bigode da gordura da sopa:/ - Dizem-me que é muito liberal a Constituição da Itália!” (I, p. 681). 
A imagem que Acácio faz de uma conversação nobre é diferente da imagem que fazem Saavedra e Julião. Este logo apimenta a conversa: "se a Itália fosse liberal devia ter há muito expulso a coronhadas o Papa, o sacro colégio, e a sociedade de Jesus!" (I, p. 681). A relação entre liberalismo e estado laico e a sugestão de escorraçar os símbolos da igreja dão outros rumos à nobreza imaginada pelo anfitrião. Acácio ainda pede "a benevolência [...] para o 'chefe da Igreja"' (I, p. 681), na tentativa de manter o "nível elevado", mas Saavedra e Julião se juntam para alfinetar a carolice de Acácio, que se vê obrigado a se defender e se revelar:

Não sou ultramontano, nem faço votos pelo restabelecimento da perseguição religiosa. Sou liberal. Creio em Deus. Mas reconheço que a religião é um freio...

- Para os que o precisam... - interrompeu Julião.

Riram; o Alves Coutinho torcia-se. O Conselheiro interdito respondeu, devagar, dispondo na travessa as rodelas do paio:

- Não o precisamos nós decerto, que somos as classes ilustradas. Mas precisa-o a massa do povo, Sr. Zuzarte. Senão veríamos aumentar a estatística dos crimes.

[...]

O Conselheiro continuava, explicando:

- Como dizia, sou liberal, mas entendo que algumas litografias ou gravuras, alusivas ao mistério da Paixão, têm o seu lugar num quarto de cama, e inspiram de certo modo sentimentos cristãos. Não é verdade, meu Jorge? (I, p. 682)

Para as classes esclarecidas, os motivos religiosos podem decorar o quarto e inspirar sentimentos cristãos. Para o povo, deverá servir de bridão. Da mesma maneira que padre Natário, durante o jantar do abade da Cortegaça n'O Crime do padre Amaro, Acácio defende que a religião é instrumento de controle popular. No jantar do abade, o tema é discutido com exaltação e gravidade; neste do Conselheiro, é tratado com ligeireza e é motivo de ironia e sarcasmo e pretexto para tiradas libertinas de Saavedra: "Eu, num quarto de dormir, as únicas pinturas que admito são uma bela ninfa nua, ou uma bacante desenfreada!” (I, p. 682)

Os convivas acham graça na observação de Saavedra e enveredam pela relação alma/corpo e, depois, voltam às mulheres pela via do casamento. Julião, maliciosamente, questiona o celibato de Acácio, que, enrubescido, mas tranquilo, culpa a idade pela falta de interesse no matrimônio: "Há muito, meu amigo, que se apagou dentro em mim o fogo das paixões" (I, p. 685). Saavedra alfineta Acácio e sugere que sexualidade masculina não se arrefece com a idade: "nenhuma idade se eximia à influência de Vênus" (I, p. p. 686). O redator do Século também aproveita para falar das preferências - "aos quinze anos gosta-se de uma matrona cheia, aos cinquenta de um frutozinho tenro..." (I, p. 686) - e fecha com o bordão do solteirão assumido: "o casamento era um fardo; não havia nada como a variedade..." (I, p. 686). Julião entende que o casamento "é uma fórmula administrativa, que há-de um dia acabar...” (I, p. 686), e continua dando ares de materialis- 
mo científico à sua tese: "a fêmea era um ente subalterno; o homem deveria aproximar-se dela em certas épocas do ano [...], fecundá-la, e afastar-se com tédio" (I, p. 686). A animalização da mulher escandaliza os convivas e Conselheiro lembra que "essas fêmeas são nossas mães, nossas carinhosas irmãs, a esposa do chefe de Estado, as damas ilustres da nobreza..." (I, p. 686). Saavedra sem concordar com Acácio nem discordar de Julião arremata "com fatuidade" e "dando palmadinhas sobre o estômago": "São o melhor bocadinho deste vale de lágrimas" (I, p. 686). E, seguindo seu apetite luxurioso, desvia o assunto para o corpo feminino. Começa pelos pés - "não havia nada como um pezinho catita!" (I, p. 686)4 - e vai à nacionalidade: "E a todas preferia a mulher espanhola!" e as francesas são perfeitas "para um bocado de cancã... Para o cancã não há como as francesas... Mas muito chupistas!” (I, p 686). Acácio tenta retomar a moralidade e lembra que as "inglesas são notáveis mães de família", mas Saavedra, interessado mais na sexualidade que na maternidade, entende que as britânicas são "frias como esta madeira [...]. Mulheres de gelo!" (I, p. 686). Alves só arregala "os olhos concupiscentes", faz "estalar a língua" e vota "pelas francesas" (I, p. 686-687).

Além de política italiana, casamento e mulheres, eles também falam da situação política de Portugal: "E o ministério, cai ou não cai?" (I, p. 683). A pergunta de Julião não motiva a exposição de princípios políticos. Os convivas tomam-na como pretexto para falar de suas insatisfações pessoais. Saavedra "declarou que [...] aquele escândalo podia continuar!". O escândalo a que ele se refere foi o grupo do poder tê-lo preterido na nomeação de um parente:

— Ele tinha-os apoiado, não é verdade? E com lealdade. [...] Sempre o fora em política! Pois bem, não lhe tinham despachado o primo recebedor de Aljustrel, tendo-lho prometido! E nem lhe tinham dado uma satisfação. Assim não era possível fazer política! (I, p. 683-684)

E Jorge não é diferente: "Jorge alegrava-se que viessem outros; talvez lhe dessem de novo a sua comissão no Ministério; e ele o que queria era estar quieto ao seu cantinho..." (I, p. 684)

A mudança desejada é somente uma maneira para reconquistar o prestígio e a posição perdidos. Só Julião parece defender uma modificação mais radical:

- Ou que caiam ou que fiquem - disse Julião - que venham estes, ou que venham aqueles... Obrigado, Conselheiro - e recebeu o seu prato de vitela - ... é-me inteiramente indiferente. É tudo a mesma podridão! [...] e esperava breve que, pela lógica das coisas, uma revolução varresse a porcaria... (I, p. 684)

A palavra revolução desperta reações conservadoras. Alves Coutinho fica "assustado, com olhares inquietos para os lados" (I, p. 684). Conselheiro lembra "os excessos da Comuna...” (I, p. 684). Julião volta à carga, 
com uma voz muito tranquila, para perguntar "onde está o mal, Sr. Conselheiro, se fuzilarmos alguns banqueiros, alguns padres, alguns proprietários obesos e alguns marqueses caquéticos! Era uma limpezazinha!...” (I, p. 684). Conselheiro cala-se e sorri do "gracejo" de Julião. E Saavedra surpreende - talvez incomodado com a possibilidade de mudanças radicais - ao declarar sua simpatia pela República:

- Eu no fundo sou republicano...

- E eu - disse Jorge.

- E eu - fez o Alves Coutinho, já inquieto. - Contem-me a mim também!

- Mas - continuou o Saavedra - sou-o em princípio. Porque o princípio é belo, o princípio é ideal! Mas a prática? Sim, a prática? - E voltava para todos os lados a sua face balofa.

- Sim, na prática! - exclamava o Alves Coutinho, em eco admirativo.

- A prática é impossível! - declarou o Saavedra. E encheu a boca de vitela. (I, p. 684)

A revolução está associada ao medo que provocam os acontecimentos recentes da Comuna de Paris. ${ }^{5}$ E a República aparece como uma possibilidade menos traumática. Além disso, a adesão é de ocasião, teórica e aparente. "Ser", aqui, significa "estar", de acordo com a conveniência. Mesmo no momento em que se questiona a lamentável condição do povo e dos trabalhadores, a maior parte do grupo tergiversa. Sebastião, questionado sobre o regime monárquico, cora, considera-se inapto para falar do tema, mas descreve sua percepção dos fatos:

parecia-lhe que os operários eram malpagos; a miséria crescia; os cigarreiros, por exemplo, tinham apenas de nove a onze vinténs por dia, e, com família, era triste...

—É uma infâmia! — disse Julião encolhendo os ombros.

— E há poucas escolas... - observou timidamente Sebastião.

—É uma torpeza! — insistiu Julião.

[...]

- Meus bons amigos, falemos de outra coisa. É mais digno de portugueses e de súditos fiéis. (I, p. 684-685)

Somente Julião apoia Sebastião na crítica às horríveis condições de educação e trabalho. Saavedra cala-se, sorri e come. E Conselheiro fecha a conversa com um apelo para voltarem à dignidade de súditos fiéis.

A considerar a atitude discursiva e gestual das personagens, a revolução assusta; antes dela, talvez seja possível pensar na República, desde que o status quo não se modifique. Durante o jantar, os seis homens conversam, às vezes exaltadamente, demonstram suas simpatias e antipatias, mas não insistem na sua defesa de ideias nem na manutenção de temas polêmicos. Considerados assim, são ótimos convivas, ${ }^{6}$ pois passam de um 
assunto a outro e não se apegam a nenhum, animando a conversa, sem deixar que as possíveis diferenças alterem demais os ânimos. Acácio é hábil para conduzir o debate e não se deixa irritar pelas provocações de Julião e Saavedra, que cedem aos pedidos do anfitrião e mantêm a "dignidade e fidelidade de súditos portugueses". Por isso, no final do jantar, a avaliação de Acácio é positiva. Ele sente "prazer [...] passar assim as horas entre amigos, de reconhecida ilustração, discutir as questões mais importantes, e ver travada uma conversação erudita" (I, p. 687).

Conversação que termina com champanhe e discursos laudatórios. No primeiro, Saavedra homenageia o anfitrião:

Conselheiro, é com o maior prazer que bebo, que todos bebemos, à saúde de um homem, que [...], pela sua respeitabilidade, a sua posição, os seus vastos conhecimentos, é um dos vultos deste país. À sua saúde, Conselheiro! (I, p. 687)

Não deixa de ser ironia, Eça ter escolhido Saavedra, conhecido pelas mentiras que escreve no Século, para propor o brinde e destacar o conhecimento e a importância de Acácio para o país. Ficará sempre uma dúvida: os elogios são falsos? Essa pergunta tem uma resposta possível, mas depois dos licores e dos charutos. Antes de chegar neles, há o discurso de conselheiro. Um pouco longo, mas vale a pena retomar os parágrafos finais:

Não esqueçamos, [...], como portugueses, de fazer votos pelo ilustrado monarca, que deu às neves da minha fronte, antes de descerem ao túmulo, a consolação de se poderem revestir com o honroso hábito de S. Tiago! Meus amigos, à família real! [...] à família modelo, que sentada ao leme do Estado, dirige, cercada dos grandes vultos da nossa política, dirige...

- Procurou o fecho; havia um silêncio ansioso - dirige...

- Através das lunetas negras, os seus olhos cravavam-se, à busca da inspiração, na travessa da aletria - dirige... Coçou a calva, aflito; mas um sorriso clareou-lhe o aspecto, encontrara a frase; e estendendo o braço - ... dirige a barca da governação pública com inveja das nações vizinhas! A família real!

— À família real! — disseram com respeito. (I, p. 688)

O brinde final não deixa dúvidas sobre a arquitetura moral de Acácio: conservador, monarquista, patriota e tudo mais que o fez merecer a distinção da Ordem de São Tiago. A conversação também serve para expor os pilares morais dos convidados: machos, celibatários ou casados, monarquistas ou republicanos de ocasião, que não querem a revolução. Até aceitam uma mudança de regime, desde que mantenham seu pecúlio, suas propriedades, sua posição social e sua influência e não tenham que mexer muitas palhas para isso. ${ }^{7}$ Têm, na ponta da língua, exclamações de repúdio à miséria, à pobreza, mas, como veremos a seguir, não se incomodam de manter as criadas a soldo baixo em casa, para inclusive, outros fins que não trinchar o assado e servir os licores. 


\section{O QUE COMES E QUEM SERVE A COMIDA}

As opções do cardápio podem ser encontradas em outras mesas burguesas das obras de Eça:" "sopa muito quente, [onde se] agitavam os longos canudos brancos e moles do macarrão", cozido, assado de vitela, peixe, acompanhados com o "arrozinho" e vinho, doces variados, licores, champanha e café. No jantar do Conselheiro, a particularidade não está nos pratos em si, ou seja, "no que os convivas comem", mas em três dados adicionais: na qualificação do repasto, nas criadas que recebem os convidados e servem os pratos e no espaço em que a ação ocorre.

"Não esperem o festim de Lúculo: é apenas o modesto passadio de um humilde filósofo!” (I, p. 681), diz Acácio quando a criada avisa que o jantar vai ser servido. A afirmação do Conselheiro pode ser lida como modéstia, pois o menu não é, nem de longe, comparável àqueles dos festins dados por Licínio Lúculo, ${ }^{9}$ general romano morto cerca de 56/57 a. C.. Esse general passou para a história pelas batalhas que travou e por oferecer faustosos banquetes, que o historiador Roy Strong (2004) classificou como dignos de "sibaritas" - referindo-se à fama dos habitantes da antiga cidade grega de Síbaris: muito ricos e cultores dos prazeres físicos, voluptuosidade e indolência. Se o jantar de Acácio não se assemelha aos de Lúculo, a comparação demonstra, além de uma relativa modéstia, que o anfitrião conhece a história e talvez aprecie a indolência e a voluptuosidade. O cultivo dos prazeres físicos, que não se revelou no discurso, vai se mostrar nas criadas e nos objetos da casa. Por isso deixei esses itens para o final da análise.

As criadas são três:

A "rapariguita" que recepciona os convidados: "Na quinta-feira, os três, [...] eram introduzidos por uma rapariguita vesga, suja como um esfregão, na sala do Conselheiro" (I, p. 678).

Filomena, "uma criada, de avental branco, muito nutrida" (I, p. 680), que anuncia o jantar e, depois, se encarrega do serviço dos pratos.

E Adelaide, a quem, já no final do jantar, Acácio pede para "trazer os licores" e que os convidados podem, então, conhecer:

uma bela mulher de trinta anos, muito branca, de olhos negros e formas ricas, com um vestido de merino azul, trazendo numa bandeja de prata, onde tremelicavam copinhos, a garrafa de cognac e o frasco de curaçau.

- Boa moça! - rosnou com o rosto aceso o Alves Coutinho. Julião quase lhe tapou a boca com a mão. E falando-lhe ao ouvido, olhando o Conselheiro, recitou:

Não ouses, temerário, erguer teus olhos

Para a mulher de César! (I, 688)

No "humilde tugúrio" de Acácio, como em outras casas burguesas, há criadas para os diferentes afazeres. A reação de Alves Coutinho e de Julião, porém, indica que talvez só ele mantenha uma rapariga jovem 
e bonita para o serviço do licor. Várias interpretações podem ser dadas à manutenção de três criadas com essas características. A mais produtiva, parece-me, deve considerar a prospecção e interiorização do espaço do Conselheiro. Da porta da rua para o quarto, vai-se do feio ao belo, do sujo ao limpo, do assexuado ao sexuado, do casto ao devasso. Por isso, Julião percebe imediatamente que Adelaide é "a mulher de César", e que, sob a capa de cordeiro celibatário, está um lobo devasso.

Quando Adelaide entra com o cognac e o curaçau, Conselheiro Acácio já levara os amigos para conhecer os espaços da casa. Apresentou a sala decorada com um quadro representando uma cena da Ilíada - "tratada a tons cor de carne, e cheia de corpos nus cobertos de capacetes" -, o mudo e triste piano e a mesa de jogo sobre a qual jaziam "dois castiçais de prata, uma galguinha de vidro transparente" e, a peça mais quente pelo uso, "uma caixa de música de dezoito peças!" (I, p. 678); a mesma caixinha que, depois do brinde final dedicado à família real, toca a marcha nupcial, enquanto Acácio distribui charutos e Adelaide serve os licores.

No escritório, ou "Sanctus Sanctorum!", com a escrivaninha de trabalho, "o tinteiro de prata, os lápis muito aparados, as réguas bem dispostas", E arrematando o arranjo, “a Carta Constitucional ricamente encadernada" e "encaixilhada, na parede, pendia a carta régia que o nomeara Conselheiro; defronte uma litografia de el-rei” (I, 679). No escritório, Julião também percebe pilhas de livros cobertos com um "xale-manta pardo".

O leitor vai conhecer o quarto, porque Julião pede para "lavar as mãos", antes de sentar à mesa para o repasto:

Acácio levou-o logo ao seu quarto e retirou-se discretamente. Julião, sempre curioso, observou, surpreendido, duas grandes litografias [...] - um Ecce homo! e a Virgem das Sete Dores. [...] Abriu então a gavetinha da mesa-de-cabeceira, e viu, espantado, uma touca e o volume brochado das poesias obscenas de Bocage! Entreabriu os cortinados fechados; e teve a consolação de verificar, - que havia sobre o travesseiro duas fronhazinhas chegadas de um modo conjugal e terno! (I, p. 680-681)

O movimento nos espaços também se faz do exterior para o interior. E é no quarto que o leitor tem diante de si, à vista, os motivos de inspiração cristã: Cristo e a Virgem. Na gaveta ou entre os cortinados, estão, no entanto, a luxúria e a devassidão: o volume das poesias obscenas de Bocage e as "fronhazinhas chegadas de um modo conjugal e terno". Quando Adelaide traz o licor, para arrematar a noitada, Julião compreende imediatamente: é dona da fronhazinha que está ternamente ao lado da de Acácio e para quem a marcha nupcial toca depois dos brindes.

Ou seja, Acácio cultiva socialmente, nos espaços mais aparentes e/ou públicos, a imagem de celibatário, de ilustrado, de monarquista, respeitador dos bons costumes burgueses, mas é um libertino, em seu quarto, amancebado com a criada. 
Acácio é uma figura simbólica da elite burguesa lisboeta do período, que procura viver de aparências. Aparências que lhe rendem um bom soldo, uma boa casa, boa comida, o amor das criadas, amigos respeitáveis, boa conversação à mesa e, vez ou outra, uma distinção do Rei. Não por acaso, a revelação final do jantar é a descoberta dos livros escondidos sob o xale-manta: "enquanto se bebia o curaçau, Julião pé ante pé dirigiu-se ao escritório, e foi erguer a ponta do xale-manta pardo que tanto o preocupava; eram rumas de livros brochados, atadas com guitas - as obras do Conselheiro intactas!" (I, p. 689)

Revela-se aqui mais uma faceta dessa sociedade de aparências. A ordem de São Tiago foi dada a Acácio também pelos livros que escreveu, mas nunca foram lidos. O estoque inteiro está lá, intacto, debaixo de um xale-manta. Saavedra estava mentindo, portanto. Ele nunca leu as obras de Acácio para saber se elas contribuíram para o engrandecimento de Portugal. Talvez não seja coincidência Saavedra ter dito que o Conselheiro era um "dos grandes vultos" da política portuguesa. Vulto, além de "importante", pode se referir à "falta de nitidez" de uma imagem. Falta de nitidez que Acácio não deixa de cultivar.

Nesse episódio do jantar, Acácio é o alvo central da irônica pena de Eça. O evento comemorativo aproxima o leitor da intimidade do Conselheiro e revela detalhes que não seriam observados em outras circunstâncias. Nesse sentido, Machado de Assis não tinha razão para identificar o episódio como acessório, mesmo considerando sua extensão, ${ }^{10}$ que está adequada à própria dinâmica da cena e às antecipações e expansões possíveis a partir dela. O zelo de Eça serviria para evidenciar a esperteza e o caráter ambíguo da personagem, sem expô-lo repentinamente. A imagem de Acácio, embora revelados os detalhes íntimos, permanece socialmente "intacta”. A as críticas que se fazem a ele podem ser estendidas a toda a uma casta da burguesia lisboeta do XIX. Burgueses que se mostram liberais e preocupados com a condição popular, mas se aproveitam da Monarquia, como se aproveitariam da República, pois suas posições são sempre de conveniência. Julião que o diga. Depois do jantar e antes do final do romance, ele participa de um concurso e, preterido, faria

um escândalo, mas... - e teve um risinho - amansaram-me! Estou num posto médico, deram-me um posto médico! Atiraram-me um osso!"

$[\ldots]$

- Agora, roê-lo.

[...] O posto médico não é mau... Em definitivo, a situação melhorara...

- Mas mesquinha, mesquinha! Não saio do atoleiro...

Estava farto de Medicina, disse depois de um silêncio. Era um beco sem saída. Devia-se ter feito advogado, político, intrigante. Tinha nascido para isso! (I, p. 730-731) 
O mais combativo e provocador dos convidados do jantar amansa-se com o osso que lhe atiram para roer e reconhece que, no país em que almoça e janta, teria sido melhor se dedicar à advocacia, à política ou à intriga, enfim. E é esse cão manso, roedor de ossos que faz o diagnóstico mais lúcido da sociedade em que vive:

Este pais, meu caro amigo, tem-se governado até aqui com expedientes. Quando vier a revolução contra os expedientes, o país há de procurar quem tenha os princípios. Mas quem tem aí princípios? Quem tem aí quatro princípios? Ninguém; têm dívidas, vícios secretos, dentes postiços; mas princípios, nem meio! Por consequência se houver três patuscos que se dêem ao trabalho de estabelecer meia dúzia de princípios sérios, racionais, modernos, positivos, o país tem de se atirar de joelhos e suplicar-lhes: "Senhores, fazei-me a honra insigne de me pôr o freio nos dentes!" Ora, eu devia ser um destes. Nasci para isso! E seca-me a idéia de que enquanto outros idiotas, mais astutos e mais previdentes, hão de estar no poleiro a reluzir ao sol, al hermoso sol portugués, como se diz nas zarzuelas, eu hei de estar a receitar cataplasmas a velhas devotas, ou a ligar as rupturas de algum desembargador caduco.

Sebastião calado pensava na outra, morta em cima.

— Estúpido país, estúpida vida! — rosnou Julião. (I, p. 731)

Estúpido país de bacharéis onde os que poderiam e deveriam indicar o caminho roem ossos, vivem de expedientes, cultivam as aparências e são indolentes, lascivos e glutões. A representação que Eça faz de Portugal e dos personagens símbolos de sua burguesia é ácida e mereceu - medida exata - todas as onze páginas. ${ }^{11} \mathrm{E}$ essa representação me permite acrescentar mais sintagmas à frase que venho reelaborando: "diga-me o que comes, [como comes], [com quem comes] e [onde, ou em que país, comes e onde guarda as sobras e os ossos] que dir-te-ei quem és.

\section{REFERÊNCIAS BIBLIOGRÁFICAS}

ALVES, Dario Moreira de Castro. Era Tormes e Amanhecia: dicionário gastronômico cultural de Eça de Queirós. Rio de Janeiro: Nordica, 1992.

ANDRADE, José Roberto de. Comer e comer: um verbo, dois (re) cortes em O Crime do Padre Amaro. Revista Eletrônica do IFBA. Ano 3, n. 3, Julho-Dezembro/2012, pp. 33-45. Disponível em <http://www.revistapindorama.ifba.edu.br/ed_atual.php >. Acesso em 16 jan. 2013.

- Culinária e modificações do gosto em Eça de Queirós: $O$ Crime do Padre Amaro e Os Maias. In: PETROV, Petar; SOUZA, Pedro Quintino de; SAMARTIM, Roberto López-Iglésias; TORRES FEIJÓ, Elias 
J. (eds.). Avanços em Literatura e Cultura Portuguesas. De Eça de Queirós a Fernando Pessoa. Santiago de Compostela - Faro: Associação Internacional de Lusitanistas - Através Editora, 2012, pp. 141-158.

- Intermitência gastronômica? Sonho, realidade e farsa $\mathrm{n}^{\prime} A$ Relíquia e n'O Mandarim. Anais do XXIII Congresso Internacional da Associação Brasileira de Professores de Literatura Portuguesa (ABRAPLIP), ISBN 978-85-7862-215-2. Disponível em: <http://www.abraplip.org/anais_abraplip/images/stories/Jose\%20Roberto\%20de\%20Andrade.pdf $>$. Acesso em 12 dez. 2012.

ASSIS, Machado. Eça de Queirós: O Primo Basílio. In: . Obra Completa. V. III. Rio de Janeiro; Aguillar, 1997, pp.903-913.

BERRINI, Beatriz (Org.). Comer e beber com Eça de Queirós. Rio de Janeiro: Index, 1995.

. Eça de Queirós e os prazeres da mesa. Semear, Rio de Janeiro, v. 01, n. 01, p. 53-66, 1997.

LIMA, Isabel Pires de. Fulgurações e Ofuscações de Eros - O Primo Basílio - In: Anais do III Encontro Internacional de Queirosianos: 150 anos com Eça de Queirós, realizado em São Paulo, 1995. São Paulo: Centro de Estudos Portugueses: Área de Estudos Comparados de Literatura de Língua Portuguesa/FFLCH/USP, 1997, p. 715-721.

MATOS, Alfredo de Campos (Org.). Dicionário de Eça de Queiroz. 2. ed. Lisboa: Caminho, 1988.

Eça de Queirós. Uma biografia. Porto: Edições Afrontamento, 2009 Autor, 2012.

. Sexo e sexualidade em Eça de Queirós. Portugal: Edições do

MONTANARI, Massimo. La Comida como cultura. Espanha: Ediciones Trea, 2004

QUEIRÓS, Eça de. Obra Completa: quatro volumes. Organização geral, introdução, fixação dos textos autógrafos e notas introdutórias Beatriz Berrini. Rio de Janeiro: Aguilar, 1997.

QUEIROZ, Maria José de. A Literatura e o gozo impuro da Comida. Rio de Janeiro: Topbooks, 1994.

QUITÉRIO, José. Livro do bem comer: crônicas de gastronomia portuguesa. Lisboa: Assírio \& Alvim,1987.

REIS, Carlos. O essencial sobre Eça de Queirós. Lisboa: Ed. Imprensa Nacional, 2000.

SAVARIN, Brillart. A fisiologia do gosto. Tradução Paulo Neves. São Paulo: Companhia das Letras, 1995. 
SOARES, Carmem; FERREIRA, José Ribeiro; FIALHO, Maria do Céu. Ética e Paideia em Plutarco. Volume integrado no projeto Plutarco e os fundamentos da identidade europeia, financiado pela Fundação para a Ciência e a Tecnologia. Investigador responsável: Delfim Ferreira Leão. Disponível em: <http://www.google.com.br/url?sa=t\&rct=j\&q=\&esrc=s\& source $=$ web \&cd $=10 \& v e d=0$ CFMQFjAJ\&url=http $\% 3 \mathrm{~A} \% 2 \mathrm{~F} \% 2$ Festudoge ral.sib.uc.pt\%2Fbitstream\%2F10316\%2F2566\%2F1\%2Fetica_e_paideia_ em_plutarco.pdf\&ei=ksBdUuPSK6Xy4QS5wIDoBw\&usg=AFQjCNGKS TDm2jjUua-km2tuaH3TKOBRHA\&bvm=bv.54176721,d.bGE\&cad=rja $>$. Acesso em: 10 out. 2013.

STRONG, Roy C. Banquete: uma história ilustrada da culinária e dos costumes e da fartura à mesa. Rio de Janeiro: Jorge Zahar Ed., 2004.

THERBORN, Göran. Sexo e Poder: A família no mundo 1900-2000. São Paulo: Contexto, 2006.

VILELA, Ana Luísa. Poética do Corpo: Imaginário e representação física n’Os Maias, de Eça de Queirós. Évora: Edições Cosmos, 2012.

. Primatas e Carnívoros n'Os Maias: elementos do discurso erótico queirosiano, a propósito de um ananás comido na "Toca”. In: Anais do III Encontro Internacional de Queirosianos: 150 anos com Eça de Queirós, realizado em São Paulo, 1995. São Paulo: Centro de Estudos Portugueses: Área de Estudos Comparados de Literatura de Língua Portuguesa/FFLCH/ USP, 1997: p. 57-64.

WERNEK, Francisco José dos Santos. As ideias de Eça de Queirós. Rio De Janeiro: Livraria AGIR Editora, 1946.

Recebido para publicação em 03/10/2013 Aprovado em 28/01/2014

\section{NOTAS}

1 Uma versão preliminar e resumida deste trabalho foi apresentada no XXIV Congresso Internacional da Associação Brasileira de Professores de Literatura Portuguesa (ABRAPLIP), em outubro de 2013, com o título "O Primo Basílio: crítica da burguesia lisboeta".

2 Os trechos da obra de Eça de Queirós foram retirados da edição, em quatro volumes, publicada pela editora Aguilar, sob a coordenação de Beatriz Berrini. Nas citações, referir-me-ei simplesmente aos volumes (I, II, III e IV) e às páginas.

3 Guardadas as circunstâncias e as diferenças físicas, o comportamento dessa personagem, quando fala dos doces a Sebastião, pode ser comparado ao do Abade da Cortegaça, n'O Crime do padre Amaro: Alves Coutinho se esquece das mulheres e fala dos doces; o abade esquece os sacramentos e, durante os sermões, dá aos fiéis receitas de bacalhau e de sarrabulhos. Para ambos, primeiro a comida, depois a religião ou os prazeres sexuais.

4 A. Campos Matos afirma que alimentação e sexualidade estão estreitamente ligadas na obra de Eça de Queirós. E a sexualidade também chega ao "pormenor fetichista" como é o caso do pé, que aparece em outros momentos d'O Primo Basílio e em outras obras de Eça. (MATOS, 2012, p. 50) 
5 O Primo Basílio foi publicado em 1880. Se considerarmos que, no jantar do Conselheiro Acácio, menciona-se, com certo "frescor", a Comuna de Paris, poderíamos localizar a ação entre 1871, data da Comuna, e 1880, data da publicação do romance.

6 O célebre Brillart Savarin, advogado, cozinheiro e gourmet francês, muito conhecido no século XIX, diria que o jantar de Acácio foi perfeito. Savarin afirma que "o prazer à mesa não comporta arrebatamentos, nem êxtases, nem transportes, mas ganha em duração o que perde em intensidade" (SAVARIN, 1995: p. 170). Ou seja, a conversa pode ser animada, mas não exaltada. Assim, estende-se o prazer da comida e do diálogo.

7 O episódio d'O Crime do Padre Amaro também traz essa mesma oposição: revolução x manutenção do status quo. E nele estão Amaro e Cônego Dias no meio da multidão que recebe pasmada diante da Casa Havanesa notícias dos "horrores" da Comuna. O pasmo dá lugar a uma certeza: padres, nobreza e burguesia juntos impedirão que a agitação chegue a Portugal.

8 Com poucas diferenças, os itens do cardápio podem ser encontrados, por exemplo, no jantar do Abade da Cortegaça, n'O Crime do Padre Amaro, e em cenas d'Os Maias. A esse respeito, veja-se Andrade, 2012 e 2013.

9 Num estudo de Plutarco sobre Lúculo, aquele dizia "que o general preferia os louvores que derivavam da justiça e da humanidade (apo dikaiosynes kai philanthropias) aos que advinham dos sucessos militares, já que estes adquiriam-se apenas numa pequena parte graças ao exército e na sua maioria por efeito da tyche ou sorte, enquanto a justiça e a humanidade são fruto de um espirito doce e culto." E “ao comparar as refeições de Lúculo com as de Cimon, contrapõe a do primeiro, faustosa como a de um satrapa, a do segundo, democrática (demokratike) e generosa (philanthropos)". (SOARES et alli, p. 23-24).

$10 \mathrm{Na}$ edição que estamos utilizando, a cena preenche onze páginas (678 a 689) do capítulo, considerando o convite feito por Acácio, até a saída dos convidados.

11 A força dessa representação pode ser percebida na adoção e posterior dicionarização do adjetivo "acaciano" que designa "que ou quem se mostra afetado, ridículo pelo uso de fórmulas convencionais ao falar ou pela maneira pomposa de ser” (In: Dicionário Houaiss de Língua Portuguesa, versão eletrônica). 